Click www.researchjournal.co.in/online/subdetail.html to purchase.

$\rightarrow$ DOI : $10.15740 / \mathrm{HAS} / \mathrm{AJBS} / 11.1 / 49-51$

e ISSN-0976-8343 | Visit us : www.researchjournal.co.in

- AFBSAH-2016 $\frac{\text { ASIAN JOURNAL OF BIO SCIENCE }}{\text { Volume } \mathbf{1 1} \mid \text { Issue } 1 \mid \text { April, 2016 |49-51 }}$

RESEARCHPAPER

\title{
In vitro floral morphogenesis in Eclipta prostrata (L.)
}

\section{RAYEES AHMAD DAR, EAPEN P. KOSHY AND GEORGE THOMAS}

Department of Molecular and Cellular Engineering, Sam Higginbottom Institute of Agriculture, Technology and Sciences, ALLAHABAD (U.P.) INDIA

Email : eapen.koshy@shiats.edu.in

Article Info :Received : 15.12.2015; Accepted : 7.02.2016

The efficacy of cytokinins in in vitro flowering of Eclipta prostrata was evaluated. The MS media fortified with Kin (4 mgl $\left.{ }^{-1}\right)$ supported the formation of 4-7 flowers and a maximum of 13 flowers was obtained in MS media fortified with $2 \mathrm{iP}\left(5 \mathrm{mgl}^{-1}\right)$. It highlights the positive role of cytokinins in in vitro floral induction.

Key words : Bhringraj, Eclipta prostrata, In vitro flowering

How to cite this paper : Dar, Rayees Ahmad, Koshy, Eapen P. and Thomas, George (2016). In vitro floral morphogenesis in Eclipta prostrata (L.) . Asian J. Bio. Sci., 11 (1) : 49-51 [Special Issue of AFBSAH-2016]. 